\title{
Computational Study of Energy Consumptions in Residential Building for Predicting Effectiveness of Various Energy Conservation Steps
}

\author{
Nidhi Gupta, Ankit Agarwal \\ Department of Mechanical Engineering, Swami Keshvanand Institute of Technology, Management \& \\ Gramothan, Jaipur-302017 (INDIA) \\ Email: nidhiengg06@gmail.com, ankit@skit.ac.in \\ Received 15.01.2021, received in revised form 18.01.2021, accepted 18.01.2021
}

\begin{abstract}
The present work aims to reduce the cost of energy for a residential building using a computer based analytical software. For analysis purpose many steps has been taken and investigated to reduce the energy consumption in the house hold, especially the segments that consume more energy. Detailed numerical analysis has been done for estimating the amount of savings in power demand and resulting paybacks period of these significant power saving steps. Following segments or power saving steps are investigated in the present study for a residential house situated in Jaipur, Rajasthan. Illumination: Replacing conventional incandescent bulbs by Light Emitting Diode (LED) lights, Electronic appliances: Replacing some old appliances such as refrigerators by high star rated appliances, Heating Ventilation and Air conditioning (HVAC): Effect of installing thermal insulation on power consumption by HVAC System, Hot water uses: Effect of replacing electric geysers by solar water heaters in the house. It has been concluded that about $59 \%$ of reduction in electricity bill has been achieved by implementing affordable energy saving steps. This study is useful for every family in India. It has been found that from total amount of reduction in electricity bill about $35 \%$ has been achieved by thermal insulation only.
\end{abstract}

Keywords- BEE star rating, Electricity consumption, LED, Payback, Power Saving, Solar water heater, Thermal insulation, Total Cost of cooling

\section{INTRODUCTION}

Typical year round meteorological data are used for the Energy simulation of the residential building. An important aspect of this modelling of energy system is that it accounts for the interaction between different elements of the residential building, such as the impact of solar heat and lighting on room airconditioning loads, impact of wall, floor, roof insulation, infiltration, people activities etc. on cooling load calculations etc.

Mitra [1] investigated the use of thermal insulation in walls and roof and reported that building walls facing the sun and the occupants of the building contributes about $60-80 \%$ of total heat gain. He reported that in total electrical energy consumption of a building, air conditioning contributes about $40-50 \%$ role. Kulkarni et al. [2] optimized cooling load for a lecture theatre in Roorkee reported that the use of false ceiling, ceramic tiles on roof and floor, $13 \mathrm{~mm}$ air gap between walls gave the best possible retrofitting option. Tyagi et al. [3] investigated the weather condition of Jaipur such as the average and extremes of temperature, rainfall and humidity. Chetia and Prashant [4] investigated Aranya bhawan, Jaipur which houses the office of Forest Department, Government of Rajasthan. A reduction of 32\% in the annual electricity consumption is estimated by using insulation of roofs and walls, using double glazed windows and effective air conditioning system.

Suziyana et al. [5] investigated heat gain in two rooms in a building and reported that the performance of air conditioning system is closely related to heat generated inside a room by its occupants and their activities. Indian green building council [6] released a bulletin on "Building insulation". According to the report, the potential $40-50 \%$ saving can be done in energy consumption by designing a building that uses natural sources for lighting and ventilation. It also suggested that thermal insulation can be applied on exterior walls, interior walls and over the roof etc. Arlan Burdick [7] of U.S. Department of energy released a guide "Strategy Guideline: Accurate Heating and Cooling Load Calculations" for accurate load calculations which have a direct impact on energy efficiency, occupant comfort, indoor air quality, and building durability etc. Abdullah and Aboud [8] also reported about the importance of using thermal insulation for building walls they also reported that cooling load and electric power consumption for air-conditioning equipment can be dropped to more than $50 \%$ if proper insulation is provided at the roof and walls.

Sayed and Sawant [9] investigated life cycle cost of energy components of a mass housing study. They found that the payback period for solar water heater is approximately 15 years and two years for energy efficient lighting using light emitting diode (LED) lights. Johan Norden et al. [10] investigated effectiveness of Light Emitting Diode (LED) lights which reduces the electricity consumption significantly. Their results indicate that on an average of $3.5 \mathrm{kWh}$ of electricity can be saved for single family house annually by replacing conventional lamps to LED lights. 
Awanish Kumar et al. [11] studied the saving in electrical energy consumption by conducting an intelligent and smart electrical energy audit under an initiative forum "MGR vision 10MW". In residential area users should think about the installation of new machines and equipment with low cost, effective and efficient techniques to achieve high efficiency of energy user. Umberto Berardi [12] suggested that in hot and humid climate of India, Considerable energy saving can be done by using renewable energy sources i.e. using highly effective cooling system. J.P. Holman [13] suggested for a model window glass panel consisting of two glasses with vacuum (approx $0.01 \mathrm{~atm}$ ) in between will reduce the heat transfer from the surrounding into the room. Prompam e al. [14] investigated on thermo-syphon solar water heater (TSSWH). They found that simple payback period for TSSWH was around 5.4 years.

Important segments are selected that consumes more electricity as compared to other segments. These energy consuming segments are then analysed in detail. Calculations are then made for monthly and annual consumption of electricity in these segments. Figure 1 represents the breakdown of electricity consumption of a general building in which $57 \%$ of electricity load were consumed by air conditioning appliances. Basis of figure 1, four segments were drawn for analysing energy cost estimation.

Following four important segments have to be studied in detail for minimizing energy cost in a residential building.

1. Illumination: Replacing conventional incandescent bulbs by Light Emitting Diode (LED) lights

2. Electronic appliances: Replacing some old appliances such as refrigerators by high star rated appliances

3. Heating Ventilation and Air conditioning (HVAC): Effect of installing thermal insulation on power consumption by HVAC System

4. Hot water uses: Effect of replacing electric geysers by solar water heaters in the house, eg. solar water heater

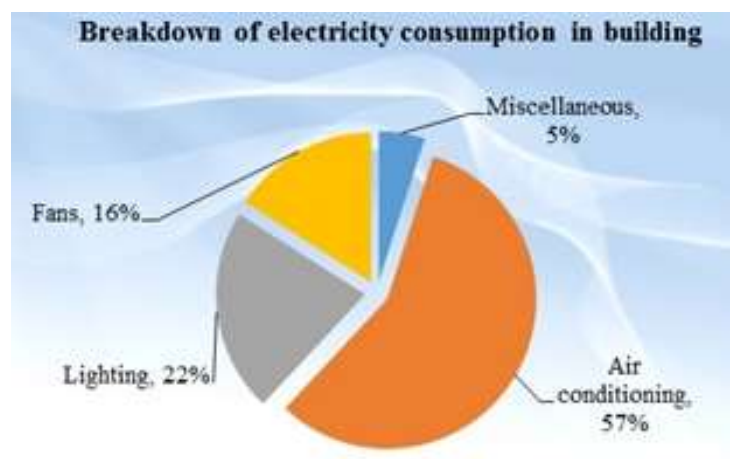

Fig.1 Breakdown of electricity consumption of a general building

The Objectives of this work is to identify and minimize electricity consumption of a residential building in four important segments (Illumination, HVAC, Hot water, electronic appliances) and to estimate payback period for all the energy saving step efficient appliances helps consumers in saving energy.

\section{METHOLOGY}

The study of electricity consumption of building has been carried out at a residential house situated at a location of Pratap Nagar, Jaipur, Rajasthan. Firstly the electricity consumption of four categories which are HVAC, hot water load, lighting load and load of other electronic appliances has been calculated by HEAT CAD. Than it is replaced by applying energy saving equipment and then calculation has made with estimate of payback period.

\section{CURRENT LOAD CALCULATIONS}

\subsection{HVAC load}

HVAC Load contributes about $40 \%$ to $60 \%$ of a building in general and in some cases even more. It includes heating and cooling load both but in Indian weather conditions heating load is not very important so only cooling load has been studied in this study

\subsubsection{Calculation of HVAC}

For calculation of cooling load, various factors have been considered by HEAT CAD. These factors are-

- Calculate inside and outside climate condition

- Wall, floor, roof and construction properties etc

- No. of occupants, their occupancy and activities

- No. of Windows, doors, skylights and their positions and glass areas

- Lighting in the rooms

- Electronic equipment used

- Infiltration

- Ventilation

Table 1 Calculation of cost of cooling load in the building

\begin{tabular}{|l|l|l|}
\hline $\begin{array}{l}\text { S. } \\
\text { No. }\end{array}$ & Particulars & Specification \\
\hline 1 & Installed A.C. specification & $\begin{array}{l}\text { Split, 5 Star } \\
\text { A.C. of Blue } \\
\text { Star }\end{array}$ \\
\hline 2 & Installed A.C. capacity in (ton) & 1.5 \\
\hline 3 & Cooling capacity in (kW) & 5.14 \\
\hline 4 & Power Input in (kW) & 1.46 \\
\hline 5 & EER (kW/kW) & 3.51 \\
\hline 6 & $\begin{array}{l}\text { No. of running hours/day on an } \\
\text { average }\end{array}$ & 6 \\
\hline 7 & No. of running months in a year & 8 \\
\hline 8 & $\begin{array}{l}\text { Total A.C. running hours per } \\
\text { month (approx) }\end{array}$ & 180 \\
\hline 9 & $\begin{array}{l}\text { Total cooling load calculated by } \\
\text { HEAT CAD (kW) }\end{array}$ & 4.62 \\
\hline 10 & $\begin{array}{l}\text { Actual power consumed by A.C. } \\
\text { to meet desired condition (kW) }\end{array}$ & 1.31 \\
\hline 11 & $\begin{array}{l}\text { Actual electricity units consumed } \\
\text { by A.C. to meet indoor desired } \\
\text { condition in a month } \\
\text { (kWh/Month) }\end{array}$ & 235.8 \\
\hline
\end{tabular}




\begin{tabular}{|l|l|l|}
\hline 12 & $\begin{array}{l}\text { Total cost of running A.C. to meet } \\
\text { indoor desired condition } \\
\text { (Rs./Day) }\end{array}$ & 55 \\
\hline 13 & $\begin{array}{l}\text { Total cost of running A.C. to meet } \\
\text { indoor desired condition } \\
\text { (Rs./Month) }\end{array}$ & 1650 \\
\hline 14 & $\begin{array}{l}\text { Total cost of running A.C. (for } \\
\text { usage of } 8 \text { months in a year) to } \\
\text { meet indoor desired comfort } \\
\text { condition (Rs. Year) }\end{array}$ & 13480 \\
\hline
\end{tabular}

Table 1 represents the calculation of cooling load in the building considering there is a requirement of cooling of one typical bedroom and Figure 2 represents the Breakdown of total cooling loads in various factors in which heat gain is added to the

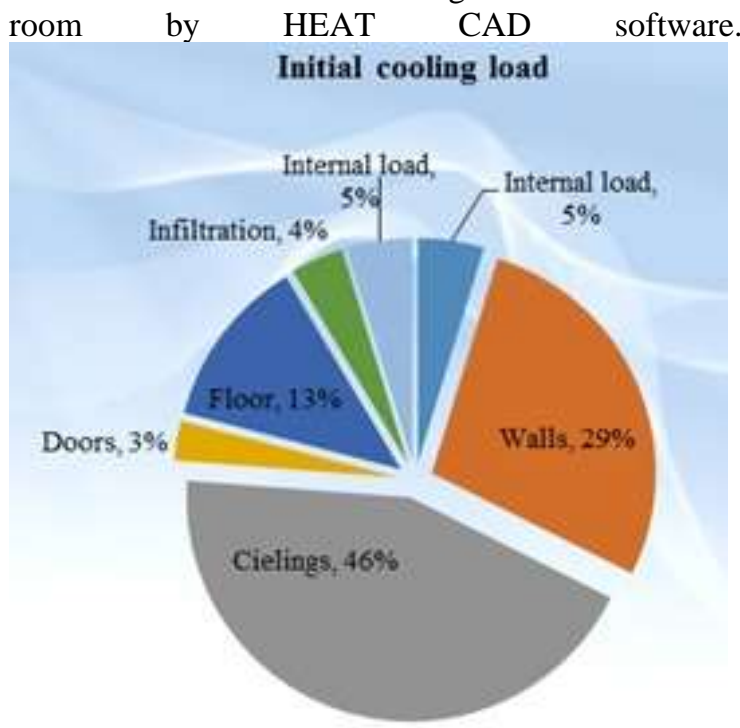

Fig. 2 Breakdown of total cooling load by HEAT CAD initially

\subsection{Load of hot water requirement}

Hot water is needed in both bathroom and kitchen in the season in which temperature is low. Geyser consume total electric units of about $4.5 \mathrm{kWh}$ in a day for fulfilling the need of 100 litre hot water. Cost of using electric geyser for this need is approximately Rs. 960 per month.

Table 2 shows the calculation of cost of getting hot water in a family containing 4 members.

Table 2 Cost of getting hot water in bathroom and kitchen

\begin{tabular}{|l|l|l|}
\hline $\begin{array}{l}\text { S. } \\
\text { No. }\end{array}$ & $\begin{array}{l}\text { Parameters related to electric water } \\
\text { heater }\end{array}$ & Value \\
\hline 1 & No. of person in family & 4 \\
\hline 2 & No. of months of hot water requirement & 6 \\
\hline 3 & Hot water requirement in Kitchen & Yes \\
\hline \multirow{2}{*}{4} & $\begin{array}{l}\text { Volume of total hot water needed in home } \\
\text { per day (approx) }\end{array}$ & $\begin{array}{l}100 \\
\text { liters }\end{array}$ \\
\hline \multirow{2}{*}{5} & $\begin{array}{l}\text { Electricity consumed by Bajaj Majesty 3 L. } \\
\text { electric geyser per day (approx) }\end{array}$ & $\begin{array}{l}4.5 \\
\mathrm{kWh}\end{array}$ \\
\hline 6 & Electricity cost per day in Rs. (approx) & 32 \\
\hline 7 & Electricity cost per month in Rs. (approx) & 960 \\
\hline 8 & Electricity cost per year in Rs. (approx) & 5856 \\
\hline
\end{tabular}

\subsection{Calculation of Lighting load}

In this study earlier total two no. of $40 \mathrm{~W}$ incandescent bulbs, four no. of $100 \mathrm{~W}$ incandescent bulbs and one CFL of $13 \mathrm{~W}$ were used for illumination. For analysis of energy consumption these all have been studied in terms of their cost of usage in a year.

Calculations of electricity consumed by all lighting devices have shown in Table 3.

Table 3 Calculation of cost of lighting load

\begin{tabular}{|c|c|c|c|c|}
\hline $\begin{array}{l}\text { S. } \\
\text { No. }\end{array}$ & Lighting devices & \begin{tabular}{|l|} 
Bulbs \\
of40 \\
Watts \\
(A) \\
\end{tabular} & \begin{tabular}{|l|} 
Bulbs of \\
100 \\
Watts \\
(B) \\
\end{tabular} & $\begin{array}{l}\text { CFL of } \\
13 \\
\text { Watts } \\
\text { (C) } \\
\end{array}$ \\
\hline 1 & Quantity & 2 & 3 & 1 \\
\hline 2 & Running Hours per day & 13 & 9 & 13 \\
\hline 3 & $\begin{array}{l}\text { Illumination by } 1 \text { piece } \\
(\mathrm{Lm})\end{array}$ & 450 & 1210 & 450 \\
\hline 4 & $\begin{array}{lll}\begin{array}{l}\text { Electric } \\
\text { day }\end{array} & \text { load(kWh) } I \\
\end{array}$ & 1.04 & 2.7 & 0.17 \\
\hline 5 & $\begin{array}{l}\begin{array}{l}\text { Electric } \\
\text { month }\end{array} \\
\end{array}$ & 31.2 & 81 & 5.07 \\
\hline 6 & Avg. Life span (hours) & 1200 & 1200 & 8000 \\
\hline 7 & Purchase cost/piece & 15 & 15 & 249 \\
\hline 8 & $\begin{array}{l}\text { Life in this study } \\
\text { (approx) }\end{array}$ & $\begin{array}{l}0.25 \\
\text { year }\end{array}$ & $\begin{array}{l}0.19 \\
\text { year }\end{array}$ & $\begin{array}{l}1.69 \\
\text { year }\end{array}$ \\
\hline 9 & $\begin{array}{l}\text { Cost of usage per month } \\
\text { (without considering } \\
\text { replacement cost) in Rs. }\end{array}$ & 218 & 567 & 36 \\
\hline 10 & $\begin{array}{l}\text { Total annual cost } \\
\text { (electricity } \\
\text { replacement) in 1st year } \\
\text { in Rs. }\end{array}$ & 2777 & 6960 & 434 \\
\hline 11 & $\begin{array}{lr}\text { Total annual cost } \\
\text { (electricity } \\
\text { replacement) by average } \\
\text { of } 8 \text { year in Rs. }\end{array}$ & 2777 & 6960 & 559 \\
\hline 12 & Total Cost & & 10296 & \\
\hline
\end{tabular}

\subsection{Load of other electronic appliances}

These are two fans, one T.V.s and one desktop monitor. Two fans are being used in bedroom and one fan is being used in guest room. One T.V. is used in bedroom and one desktop monitor is used with computer. Table 4 shows the calculation of costs of using old electronic appliances.

Table 4 Calculation of cost of electric load by other (old)

\begin{tabular}{|c|c|c|c|c|}
\hline $\begin{array}{l}\text { S. } \\
\text { No. }\end{array}$ & Equipment & $\begin{array}{l}\text { Fans } \\
\text { (For 8 } \\
\text { months) }\end{array}$ & $\begin{array}{l}\text { T.V. } \\
\text { (CRT) }\end{array}$ & $\begin{array}{l}\text { Desktop } \\
\text { monitor } \\
\text { (CRT) }\end{array}$ \\
\hline 1 & Specifications & 92 Watt & $\begin{array}{l}110 \\
\text { Watt }\end{array}$ & $\begin{array}{l}100 \\
\text { Watt }\end{array}$ \\
\hline 2 & Quantity & 2 & 1 & 1 \\
\hline 3 & Power used (kW) & 0.09 & 0.11 & 0.1 \\
\hline 4 & $\begin{array}{l}\text { No. of hours of } \\
\text { usage per day }\end{array}$ & 8 & 3 & 4 \\
\hline 5 & $\begin{array}{l}\text { Electric units } \\
\text { consumed } \\
(\mathrm{kWh}) / \text { day }\end{array}$ & 1.44 & 0.33 & 0.4 \\
\hline 6 & $\begin{array}{l}\text { Electric } \\
\text { consumed by old } \\
\text { appliances } \\
\text { month }\end{array}$ & 43.2 & 9.9 & 12 \\
\hline 7 & $\begin{array}{l}\text { Electricity cost / } \\
\text { month (Rs.) }\end{array}$ & 302 & 69 & 84 \\
\hline 8 & $\begin{array}{l}\text { Electricity cost/ year } \\
\text { (Rs.) }\end{array}$ & 2470 & 843 & 1022 \\
\hline 9 & Total Cost & 4335 & & \\
\hline
\end{tabular}




\subsection{Calculation of electricity bill}

Table 5 represents the calculation of electricity bill seasonally by considering all segments for a residential house.

Table 5 Monthly contribution in electricity bill by all segments

\begin{tabular}{|l|l|l|l|}
\hline $\begin{array}{l}\text { S. } \\
\text { No. }\end{array}$ & Name of segment & $\begin{array}{l}\text { Initial } \\
\text { contribution } \\
\text { in electric bill/ } \\
\text { month } \\
\text { (Rs.) }\end{array}$ & $\begin{array}{l}\text { Initial } \\
\text { contribution in } \\
\text { electric } \\
\text { Bill/year } \\
\text { (Rs.) }\end{array}$ \\
\hline 1 & HVAC & 1650 & 13480 \\
\hline 2 & Need of hot water & 960 & 5856 \\
\hline 3 & Fan & 302 & 2470 \\
\hline 4 & Illumination & 821 & 10335 \\
\hline 5 & T.V.+ Monitor & 153 & 1865 \\
\hline 6 & Other segments & 200 & 2400 \\
\hline 7 & $\begin{array}{l}\text { Basic fix charges } \\
\text { and taxes etc. in } \\
\text { bill }\end{array}$ & 400 & 4800 \\
\hline $\begin{array}{l}\text { Monthly bill in summers } \\
\text { [Sum of 1 + (3 to 7)] }\end{array}$ & 3526 & - \\
\hline $\begin{array}{l}\text { Monthly bill in winters } \\
\text { [Sum of 2 + (4 to 7)] }\end{array}$ & 2534 & - \\
\hline
\end{tabular}

\section{METHODS AND CALCULATIONS OF REDUCTION OF CURRENT LOAD}

Cost of implementation, amount of savings in terms of reduction in electricity bill produced by these energy saving plans have been analysed.

\subsection{Reduction of electricity cost of $\mathrm{HVAC}$}

\subsubsection{Polyurethane foam insulation}

Applying thermal insulation of polyurethane foam (PUF) board on inside walls and polyurethane foam insulated roofing panel on the top of the roof. It has good thermal insulating properties, relatively high mechanical strength and low density. In addition, it is relatively easy and economical to install. Polyurethane foam is effective as an insulator because it has a high proportion of non-connected closed microcells, filled with inert gas.

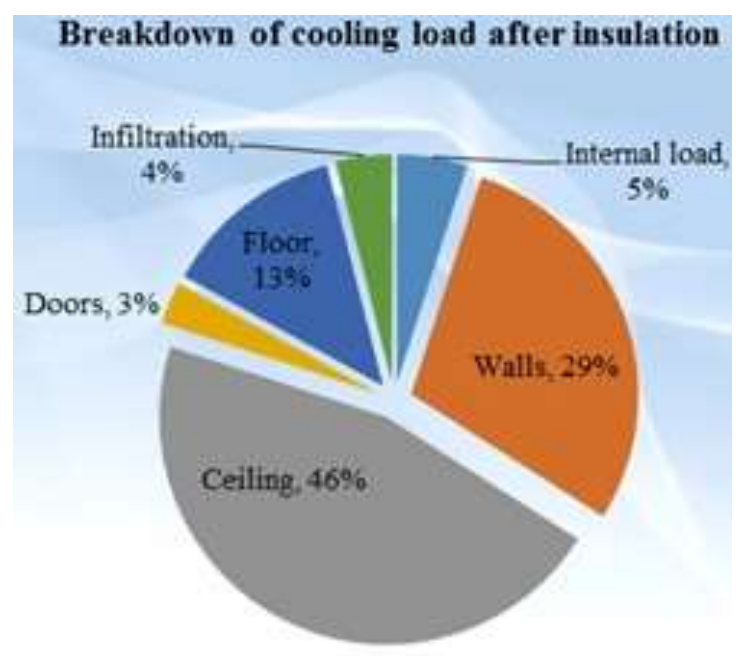

Fig. 3 Breakdown of cooling load by HEAT CAD after thermal insulation

Pie chart of breakdown of sensible cooling load for different segments like floors, ceilings, walls, doors etc. after installing thermal insulation has been shown in Figure 3. Table 6 represents the reduction in the operating cost of cooling device after applying thermal insulation.

Table 6 Reduction in cooling cost

\begin{tabular}{|c|c|c|c|}
\hline $\begin{array}{l}\text { S. } \\
\text { No. }\end{array}$ & Bedroom condition & $\begin{array}{l}\text { Initial } \\
\text { condition } \\
\text { (Before } \\
\text { insulation) } \\
\end{array}$ & $\begin{array}{l}\text { Final } \\
\text { condition } \\
\text { (After } \\
\text { insulation) } \\
\end{array}$ \\
\hline 1 & $\begin{array}{l}\text { Installed } \\
\text { specification }\end{array}$ & $\begin{array}{l}\text { Split,5 Star } \\
\text { A.C. of Blue } \\
\text { Star }\end{array}$ & $\begin{array}{l}\text { Split,5 Star } \\
\text { A.C. of Blue } \\
\text { Star }\end{array}$ \\
\hline 2 & $\begin{array}{l}\text { Installed A.C. capacity } \\
\text { in (Ton) }\end{array}$ & 1.5 & 1.5 \\
\hline 3 & $\begin{array}{l}\text { Cooling capacity in } \\
(\mathrm{kW})\end{array}$ & 5.14 & 5.14 \\
\hline 4 & Power Input in $(\mathrm{kW})$ & 1.46 & 1.46 \\
\hline 5 & $\mathrm{EER}(\mathrm{kW} / \mathrm{kW})$ & 3.51 & 3.51 \\
\hline 6 & $\begin{array}{l}\text { No. of running } \\
\text { hours/day }\end{array}$ & 6 & 6 \\
\hline 7 & $\begin{array}{l}\text { No. of running months } \\
\text { in a year }\end{array}$ & 8 & 8 \\
\hline 8 & $\begin{array}{l}\text { Total A.C. running } \\
\text { hours/month (approx) }\end{array}$ & 180 & 180 \\
\hline 9 & $\begin{array}{l}\text { Total cooling load } \\
\text { calculated by HEAT } \\
\text { CAD }(\mathrm{kW})\end{array}$ & 4.62 & 1.69 \\
\hline 10 & $\begin{array}{l}\text { Actual power } \\
\text { consumed by A.C. to } \\
\text { meet desired condition } \\
(\mathrm{kW})\end{array}$ & 1.31 & 0.48 \\
\hline 11 & $\begin{array}{l}\text { Actual electricity units } \\
\text { consumed by A.C. to } \\
\text { meet indoor desired } \\
\text { condition in a month } \\
(\mathrm{kWh} / \text { Month) }\end{array}$ & 235.8 & 86.66 \\
\hline 12 & $\begin{array}{l}\text { Total cost of running } \\
\text { A.C. to meet indoor } \\
\text { desired r condition } \\
\text { (Rs./Day) }\end{array}$ & 55 & 20 \\
\hline 13 & $\begin{array}{l}\text { Total cost of running } \\
\text { A.C. to meet indoor } \\
\text { desired condition } \\
\text { (Rs./Month) }\end{array}$ & 1650 & 607 \\
\hline 14 & $\begin{array}{l}\text { Total cost of running } \\
\text { A.C. to meet indoor } \\
\text { desired condition } \\
\text { (Rs./Near) }\end{array}$ & 13480 & 4954 \\
\hline
\end{tabular}

Table 7 shows the calculation of cost of getting hot water by solar water heater and then compared with electric water heater.

\subsection{Reducing cost of illumination}

Table 8 represents the comparison between cost of lighting by incandescent bulbs, CFL and LED with their replacement cost. 
Table 8 Reduction in cost of lighting by using LEDs in place of bulbs and CFL

\begin{tabular}{|c|c|c|c|c|c|c|c|}
\hline $\begin{array}{l}\text { S. } \\
\text { No. }\end{array}$ & Parameters & $\begin{array}{l}\text { Bulbs of } \\
40 W\end{array}$ & $\begin{array}{c}\text { Replaced } \\
\text { by } 4 \text { W LED }\end{array}$ & $\begin{array}{c}\text { Bulbs } \\
\text { of } 100 W\end{array}$ & $\begin{array}{c}\text { Replaced } \\
\text { by } 13 W \text { LED }\end{array}$ & $\begin{array}{c}\text { CFL } \\
\text { of } \\
13 W\end{array}$ & $\begin{array}{c}\text { Replaced by } \\
\text { 4W LED }\end{array}$ \\
\hline 1 & Quantity & 2 & 2 & 3 & 3 & 1 & 1 \\
\hline 3 & Illumination by 1 piece & 450 & 450 & 1210 & 1210 & 450 & 450 \\
\hline 4 & Electric load (kWh)/ day & 1.04 & 0.104 & 2.7 & 0.351 & 0.17 & 0.05 \\
\hline 5 & Electric load $(\mathrm{kWh}) /$ month & 31.2 & 3.12 & 81 & 10.53 & 5.07 & 1.56 \\
\hline 7 & Purchase cost/piece & 15 & 295 & 15 & 449 & 249 & 295 \\
\hline 8 & Life in this study (approx) & 0.25 year & 10.54 years & 0.19 year & 13.70 years & $\begin{array}{c}1.69 \\
\text { years }\end{array}$ & 10.54 years \\
\hline 9 & $\begin{array}{c}\text { Cost of usage per month } \\
\text { (without adding replacement } \\
\text { cost) in Rs. }\end{array}$ & 218 & 22 & 567 & 74 & 36 & 11 \\
\hline
\end{tabular}

Table 9 Reduction in electric load by using high star rated appliances

\begin{tabular}{|c|c|c|c|c|}
\hline $\begin{array}{l}\text { S. } \\
\text { No. }\end{array}$ & $\begin{array}{l}\text { Parameters } \\
\text { appliances }\end{array}$ & Fans & T.V. & Monitor \\
\hline 1 & Quantity & 2 & 1 & 1 \\
\hline 2 & $\begin{array}{l}\text { Power used by } 1 \text { old } \\
\text { appliance }(\mathrm{kW})\end{array}$ & 0.09 & 0.11 & 0.1 \\
\hline 3 & $\begin{array}{l}\text { Power used by } 1 \text { new } \\
\text { replaced star appliance } \\
(\mathrm{kW})\end{array}$ & 0.05 & 0.04 & 0.01 \\
\hline 4 & $\begin{array}{l}\text { No. of hours of usage per } \\
\text { day }\end{array}$ & 8 & 3 & 4 \\
\hline 5 & $\begin{array}{l}\text { Price of new purchased } \\
\text { energy star appliance }\end{array}$ & 1800 & 5490 & 3490 \\
\hline 6 & $\begin{array}{l}\text { Actual extra expense for } \\
\text { purchasing new } \\
\text { appliance in exchange } \\
\text { offer }\end{array}$ & 1200 & 4490 & 3000 \\
\hline 7 & $\begin{array}{l}\text { Electric units consumed } \\
\text { by old appliances }(\mathrm{kWh}) \\
I \text { month }\end{array}$ & 43 & 9.9 & 12 \\
\hline 8 & $\begin{array}{l}\text { Electric units consumed } \\
\text { by star appliances }(\mathrm{kWh}) \\
I \text { month }\end{array}$ & 24 & 3.24 & 1.2 \\
\hline 9 & $\begin{array}{l}\text { Cost of using old } \\
\text { appliances per month } \\
\text { (Rs.) }\end{array}$ & 302 & 69 & 84 \\
\hline 10 & $\begin{array}{l}\text { Cost of using star } \\
\text { appliances per month } \\
\text { (Rs.) }\end{array}$ & 168 & 22.68 & 8.4 \\
\hline 11 & $\begin{array}{l}\text { Cost of using old } \\
\text { appliances per year (Rs.) }\end{array}$ & 2470 & 843 & 1022 \\
\hline 12 & $\begin{array}{l}\text { Cost of using star } \\
\text { appliances per year (Rs.) }\end{array}$ & 1372 & 276 & 102 \\
\hline
\end{tabular}

Table 10 Savings and payback period of thermal insulation

\begin{tabular}{|c|c|c|c|c|}
\hline Room & $\begin{array}{c}\text { Cost of } \\
\text { installation } \\
\text { (Rs.) }\end{array}$ & $\begin{array}{c}\text { Monthly } \\
\text { savings in } \\
\text { electricity } \\
\text { cost } \\
\text { achieved in } \\
\text { summers } \\
\text { (Rs.) }\end{array}$ & $\begin{array}{c}\text { Annual } \\
\text { savings } \\
\text { achieved in } \\
\text { electricity } \\
\text { cost (usage } \\
\text { of 8 } \\
\text { months) } \\
\text { (Rs.) }\end{array}$ & $\begin{array}{c}\text { Payback } \\
\text { period } \\
\text { (Years) }\end{array}$ \\
\hline Bedroom & 29692 & 1043 & 8526 & 3.48 \\
\hline
\end{tabular}

\subsection{Reducing operating cost of other electronic appliances}

Table 9 represents the calculation of cost of electricity consumption by replacing old appliances with new appliances having high BEE star ratings.

\section{CALCULATION OF PAYBACK PERIOD AND SAVINGS}

Payback period is the period in which cost of installation will be recovered by savings generated. In this study 4 different energy saving steps have been implemented which plays vital role in reducing energy cost of residential building.

\subsection{Payback period and savings generated by thermal insulation}

Installation cost of $75 \mathrm{~mm}$ thickness board of polyurethane foam board from inside walls and polyurethane foam roofing panel on the top of the roof is about Rs. $400 / \mathrm{m} 2$ in Jaipur. Table 10 represents the payback period of applying thermal insulation for reducing cooling load.

\subsection{Payback period and savings generated by solar water heater}

It has been seen in this study that by installing solar water heater approximately 60-70 \% savings of electricity cost is achieved. Table 11 shows the payback period for installing solar water heater for hot water in winter and concluded that annual saving achieved by solar water heater is about Rs. 4127 . In this study solar water heater has been purchased in Jaipur at total cost (including installation) of Rs. 15000 for 100 litre capacity.

According to Venus home appliances, India the solar water heater can produce savings of up to $70 \%$ of cost of usage of electric geyser with a payback period of 3-4 years 
Table 11: Savings and payback period of solar water heater

\begin{tabular}{|c|c|c|c|}
\hline $\begin{array}{c}\text { Cost of } \\
\text { installation } \\
\text { (Rs.) }\end{array}$ & $\begin{array}{c}\text { Monthly } \\
\text { savings } \\
\text { achieved in } \\
\text { electricity cost } \\
\text { (Rs.) }\end{array}$ & $\begin{array}{c}\text { Annual savings } \\
\text { achieved in } \\
\text { electricity cost } \\
\text { (Rs.) }\end{array}$ & $\begin{array}{c}\text { Payback } \\
\text { period } \\
\text { (Year) }\end{array}$ \\
\hline 15000 & 676 & 4127 & 3.63 \\
\hline
\end{tabular}

\subsection{Payback period and savings generated by LED} lights

It has been observed that due to continuous decrement in prices of LED lights and support by government these are continuously going to be very popular and most affordable solution for high electricity bill of any family. According to different manufacture and other resource also it generally has life span of 50000 hours of usage.as per daily no of hours of usage it can sustain for more than 8 years. Table 12 represents the payback period by using LED lights in place of incandescent bulb.

Table 12 Savings and payback period of LED lights

\begin{tabular}{|c|c|c|c|c|c|}
\hline $\begin{array}{l}\text { S. } \\
\text { No. }\end{array}$ & $\begin{array}{c}\text { Type of } \\
\text { replacement }\end{array}$ & 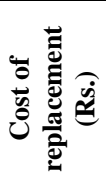 & $\begin{array}{l}\text { Monthly } \\
\text { savings } \\
\text { achieved } \\
\text { in cost of } \\
\text { usage } \\
\text { (Rs.) }\end{array}$ & $\begin{array}{c}\text { Annual } \\
\text { savings } \\
\text { achieved } \\
\text { in cost } \\
\text { of usage } \\
\text { (Rs.) }\end{array}$ & 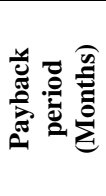 \\
\hline 1 & $\begin{array}{l}2 \text { bulbs of } \\
40 W \text { By } 2 \\
\text { LED of } 4 W\end{array}$ & 590 & 196 & 2511 & 3 \\
\hline 2 & $\begin{array}{l}3 \text { bulbs of } \\
100 \mathrm{~W} \text { by } 3 \\
\text { LED of } 13 \mathrm{~W}\end{array}$ & 1347 & 493 & 6227 & 2.73 \\
\hline 3 & $\begin{array}{l}1 \text { CFLof13W } \\
\text { by } 1 \text { LED of } \\
4 \mathrm{~W}\end{array}$ & 295 & 25 & 301 & 12 \\
\hline 4 & Total & 2232 & 714 & 9039 & 3.13 \\
\hline
\end{tabular}

Table 13 Savings and payback period of energy star rated appliance

\begin{tabular}{|c|c|c|c|c|c|}
\hline $\begin{array}{c}\text { S. } \\
\text { No. }\end{array}$ & $\begin{array}{c}\text { Type of } \\
\text { replacement }\end{array}$ & 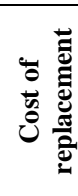 & $\begin{array}{c}\text { Monthly } \\
\text { savings } \\
\text { achieved } \\
\text { in cost of } \\
\text { usage } \\
\text { (Rs.) }\end{array}$ & $\begin{array}{c}\text { Annual } \\
\text { savings } \\
\text { achieved } \\
\text { in cost of } \\
\text { usage } \\
\text { (Rs.) }\end{array}$ & 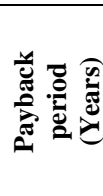 \\
\hline 1 & $\begin{array}{l}2 \text { old fans of } 92 \\
\mathrm{~W} \text { by } 2 \text { star } \\
\text { rated fans } \\
\text { of } 50 \mathrm{~W}\end{array}$ & 3200 & 134 & 1098 & 2.9 \\
\hline 2 & $\begin{array}{l}1 \text { CRT T.V. of } \\
110 \mathrm{~W} \text { by } 1 \\
\text { LED T.V. of } \\
40 \mathrm{~W}\end{array}$ & 4490 & 46 & 567 & 7.92 \\
\hline 3 & $\begin{array}{l}1 \text { CRT Monitor } \\
100 \mathrm{~W} \text { by LED } \\
\text { Monitor of } \\
10 \mathrm{~W}\end{array}$ & 3000 & 76 & 920 & 3.26 \\
\hline 4 & Total & 10690 & 256 & 2585 & 4.14 \\
\hline
\end{tabular}

\subsection{Payback period and savings from high energy} star rated appliances

In this study currently two fans, one cathode ray tube (CRT) T.V. and one CRT desktop monitor have been replaced by star rated appliances.
Payback period and annual savings by high star rated appliances has been calculated and shown in Table 13.

\subsection{Most affordable sequence to invest in energy saving plans}

Total payback period of applying all energy saving plans collectively has been achieved of about 2.37 years as represented in Table 14.

Table 14 Most affordable sequence to implement energy saving plans

\begin{tabular}{|c|c|c|c|c|}
\hline $\begin{array}{l}\text { No. } \\
\text { of } \\
\text { sequ } \\
\text { ence }\end{array}$ & $\begin{array}{l}\text { Description of } \\
\text { energy saving } \\
\text { plan }\end{array}$ & $\begin{array}{l}\text { Cost of } \\
\text { implem } \\
\text { entation } \\
\text { (Rs.) }\end{array}$ & $\begin{array}{l}\text { Saving } \\
\text { s } \\
\text { achieve } \\
\text { d per } \\
\text { year } \\
\text { (Rs.) }\end{array}$ & $\begin{array}{l}\text { Paybac } \\
\text { k } \\
\text { period } \\
\text { (Years } \\
\text { ) }\end{array}$ \\
\hline $1^{\text {st }}$ & $\begin{array}{l}2 \text { Bulbs of } 40 \mathrm{~W} \\
\text { replaced by } 2 \\
\text { LEDs of } 4 \mathrm{~W}\end{array}$ & 590 & 2511 & 0.23 \\
\hline $2^{\text {nd }}$ & $\begin{array}{l}3 \text { Bulbs of } 100 \mathrm{~W} \\
\text { replaced by } 3 \\
\text { LEDs of } 13 \mathrm{~W}\end{array}$ & 1347 & 6227 & 0.22 \\
\hline $3^{\text {rd }}$ & $\begin{array}{l}1 \mathrm{CFL} \text { of } 13 \mathrm{~W} \\
\text { replaced by } 1 \mathrm{LED} \\
\text { of } 4 \mathrm{~W}\end{array}$ & 295 & 301 & 1 \\
\hline $4^{\text {th }}$ & $\begin{array}{l}\text { Electric geyser } \\
\text { replaced by Solar } \\
\text { water heater }\end{array}$ & 15000 & 4127 & 3.63 \\
\hline $5^{\text {th }}$ & $\begin{array}{l}\text { Replacing other } \\
\text { old appliances by } \\
\text { star appliances }\end{array}$ & 10690 & 2585 & 4.14 \\
\hline $6^{\text {th }}$ & $\begin{array}{l}\text { Installing thermal } \\
\text { insulation }\end{array}$ & 29692 & 8526 & 3.48 \\
\hline \multicolumn{2}{|l|}{ Total } & 57614 & 24277 & 2.37 \\
\hline
\end{tabular}

\section{RESULTS AND DISCUSSIONS}

By investing Rs. 57614 at one time, savings of Rs. 24277/- has been achieved every year and actual total payback period will be about 2.37 year only for implementing all energy saving steps. In Table 15, reductions in consumption of electricity in important segments which have been analysed in this study has been summarized.

Table 15 Summary of all the minimization of electricity achieved in selected segments

\begin{tabular}{|c|c|c|c|c|c|c|}
\hline \multirow[b]{3}{*}{$\underset{\dot{n}}{\stackrel{0}{\dot{n}}}$} & \multirow[b]{3}{*}{$\begin{array}{l}\text { Name of } \\
\text { segment }\end{array}$} & \multicolumn{4}{|c|}{$\begin{array}{c}\text { Contribution in electricity } \\
\text { bill (Rs.) }\end{array}$} & \multirow{3}{*}{ 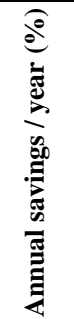 } \\
\hline & & \multicolumn{2}{|c|}{ Monthly } & \multicolumn{2}{|c|}{ Annually } & \\
\hline & & ص. & 总 & ๑气 & 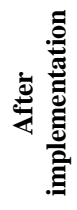 & \\
\hline 1 & $\begin{array}{l}\text { HVAC } \\
\text { (Required } \\
\text { for } 8 \\
\text { months) }\end{array}$ & 1650 & 607 & 13480 & 4954 & 63.25 \\
\hline 2 & $\begin{array}{l}\text { Hot water } \\
\text { (Required } \\
\text { for } 6 \\
\text { months) }\end{array}$ & 960 & 284 & 5856 & 1729 & 70.47 \\
\hline
\end{tabular}




\begin{tabular}{|c|l|c|c|c|c|c|}
\hline 3 & $\begin{array}{l}2 \text { Fans } \\
\text { (Required } \\
\text { for 8 } \\
\text { months) }\end{array}$ & 302 & 168 & 2470 & 1372 & 44.45 \\
\hline 4 & Illumination & 821 & 107 & 10335 & 1296 & 87.46 \\
\hline 5 & $\begin{array}{l}1 \text { T.V. + } 1 \\
\text { Monitor }\end{array}$ & 153 & 31 & 1865 & 378 & 79.73 \\
\hline 6 & $\begin{array}{l}\text { Other } \\
\text { segments }\end{array}$ & 200 & 200 & 2400 & 2400 & 0 \\
\hline 7 & $\begin{array}{l}\text { Other } \\
\text { charges in } \\
\text { bill }\end{array}$ & 400 & 400 & 4800 & 4800 & 0 \\
\hline $\begin{array}{l}\text { Approximate } \\
\text { monthly bill in } \\
\text { summers [1 + (3 to } \\
7)]\end{array}$ & 3526 & 1513 & - & - & - \\
\hline $\begin{array}{l}\text { Approximate } \\
\text { monthly bill in } \\
\text { winters [2 + (4 to } \\
7)]\end{array}$ & 2534 & 1022 & - & - & - \\
\hline $\begin{array}{l}\text { Total bill/ year } \\
\text { (Sum of 1 to 7) }\end{array}$ & - & - & 41206 & 16929 & 59 \\
\hline
\end{tabular}

According to result achieved it is observed that before implementation of all energy saving plans annual electricity bill of home was about Rs. 41206 but after implementing all energy saving steps annual electricity bill reduced to amount of Rs. 16929 only. In Table 16, annual electricity bill and total annual savings achieved by implementation of all energy saving steps has been explained.

Table 16: Total savings achieved by all energy saving steps

\begin{tabular}{|c|c|c|c|c|}
\hline Parameter & $\begin{array}{c}\text { Bill before } \\
\text { implementation } \\
\text { (Rs.) }\end{array}$ & $\begin{array}{c}\text { Bill after } \\
\text { implementation } \\
\text { (Rs.) }\end{array}$ & $\begin{array}{c}\text { Total } \\
\text { annual } \\
\text { savings } \\
\text { (Rs.) }\end{array}$ & $\begin{array}{c}\text { Total } \\
\text { annual } \\
\text { savings } \\
(\%)\end{array}$ \\
\hline $\begin{array}{c}\text { Total } \\
\text { electricity } \\
\text { bill of } \\
\text { building per } \\
\text { year (on an } \\
\text { average) }\end{array}$ & 41206 & 16929 & 24277 & 59 \\
\hline
\end{tabular}

Table 17: Total Payback period achieved by all energy saving steps

\begin{tabular}{|c|l|c|}
\hline $\begin{array}{c}\text { S. } \\
\text { No. }\end{array}$ & Description of energy saving steps & $\begin{array}{c}\text { Payback period } \\
\text { (Years) }\end{array}$ \\
\hline 1 & $\begin{array}{l}\text { 2 Bulbs of 40W replaced by 2 LEDs } \\
\text { of 4W }\end{array}$ & 0.23 \\
\hline 2 & $\begin{array}{l}\text { 3 Bulbs of 100 W replaced by 3 LEDs } \\
\text { of 13W }\end{array}$ & 0.22 \\
\hline 3 & $\begin{array}{l}\text { 1 CFL of 13 W replaced by 1 LED of } \\
4 \text { W }\end{array}$ & 1 \\
\hline 4 & $\begin{array}{l}\text { Electric geyser replaced by Solar } \\
\text { water heater }\end{array}$ & 3.63 \\
\hline 5 & $\begin{array}{l}\text { Replacing old Fan, T.V. and monitor } \\
\text { by star rated } \\
\text { appliances }\end{array}$ & 4.14 \\
\hline 6 & $\begin{array}{l}\text { Installing thermal insulation } \\
\text { Total Payback period of all energy } \\
\text { saving steps }\end{array}$ & 3.48 \\
\hline
\end{tabular}

The major outcome of this extensive study is that after implementing all above energy saving methods reduction in annual energy cost of residential building has been achieved to about $59 \%$ by only small investments. So it has been found that smart investments in energy saving steps are worth. A user from middle income group can also afford energy saving steps in sequential way as per his financial capability because it has been analyzed that one can invest further in costly energy saving steps from the earned savings itself. One can easily start energy savings by replacing incandescent bulbs by LED lights. The fastest payback period has been achieved in replacement of incandescent bulbs by LED lights. The total payback period of implementation of all energy saving steps has been achieved for about 2.37 years only as shown in Table 17 .

\section{CONCLUSION}

In this study a residential building in Jaipur city has been considered for calculating and simulating the home energy cost. A small family of four members resides in this building. It has been concluded that about $59 \%$ of reduction in electricity bill has been achieved by implementing affordable energy saving steps. This study is useful for every family. It has been found that from total amount of reduction in electricity bill about $35 \%$ has been achieved by thermal insulation only. Hence HVAC is an important segment for purpose of minimizing energy cost of a building. Conclusion has been achieved that by investing Rs. 57614 at one time one can get savings of Rs. 24277 every year and actual payback period has been achieved for about 2.37 years only. Smart investment strategy for implementing these steps has also been designed so that a middle class family can easily find convenient and affordable way to get more savings without much financial burden of initial investment. Cost of installing thermal insulation and photo voltaic panel is high but a middle class family can initially start energy savings from small affordable steps. It is easier for a family to invest in further costly energy saving steps from savings achieved from affordable energy saving steps. The speediest payback has been shown by replacement of bulbs by LED lights. Installing LED lights is a cheapest way which can be afforded by anyone and energy savings can be achieved from very first day. This study is useful for every citizen as Government of India is also encouraging energy savings by providing subsidies in different segments like solar water heater, buying LED lights for residential buildings etc.

This study is a big move towards Zero energy cost buildings or energy efficient homes. Similarly different energy saving plans can benefit people by implementing in offices, hostels, hotels and Industries etc.

Lot of initiatives has been taken by private as well as Government organizations in area of energy conservation. New evolutions in energy savings are highly appreciated everywhere because these are simple, beneficial and can be applied easily. Initially only old fan, cathode ray tube type T.V., monitor are 
replaced in this study by new energy star rated appliance due to low budget of a middle class family. Later on more appliances can also be replaced by energy efficient star rated appliances like refrigerator, microwave oven etc. Coatings on window glass, door glass and skylights etc. can also be installed to reduce heat gain from fenestration through glass. Heat gain from floor can be reduced by carpet. Such more solutions can be found and implemented by further study, these are beneficial for everyone.

\section{REFERENCES}

[1] K. K. Mitra, "Upgraded thermal insulation system for energy savings," in AIC Tech 2013 on Energy Efficiency : The Road Map to a Sustainable Future by ASHRAE India Chapter, New Delhi, pp. 4-82, September 14, 2013.

[2] K. Kulkarni, P. K. Sahoo, and M. Mishra, "Optimization of cooling load for a lecture theatre in a composite climate in India," Energy and Buildings, vol. 43, pp. 1573-1579, 2011.

[3] Ajit Tyagi, 0. P. Singh, S. S. Singh, and Surendra Kumar, Climate of Jaipur.: Meteorological Centre, Jaipur, India Meteorological Department, Ministry of Earth Sciences, Government of India, pp. 4-11, 2011.

[4] Saswati Chetia, Prashant Bhanware, Kira Cusack, Pierre Jaboyedoff and Sameer Maithel, "Energy efficient building design: A case-study of Aranya bhawan, Jaipur," in International Conference on Implementing Energy Efficiency in Buildings, New Delhi, December 17-18, 2015, pp. 113-122.

[5] M. D. Suziyana, S. N. Nina, T. M. Yusof, and A. A. S. Basirul, "Analysis of Heat Gain in Computer Laboratory and Excellent Centre by using CLTD/CLF/SCL Method," Procedia Engineering, vol. 53, pp. 655-664, 2013.

[6] Bulding Insulation [Online]. https://igbc.in/igbc/htmlpdfs/technical/Building $\% 20$ Insulation, pdf, pp. 1-4, (accessed on November 6, 2015)

[7] Arlan Burdick, "Strategy guideline: Accurate heating and cooling lad calculations," Building America, U.S. Department of Energy, Guide, pp. 1-47, June, 2011.

[8] Hassan Kareem Abdullah and Sajad M. Aboud, "Reduction of heat transfer through walls in buildings by using Insulation," International Journal of Computer Applications, vol. 141, no. 4, pp. 975-8887, May 2016.

[9] Shagufta Sajid Mumtaaz Sayed and Priyadarshi H. Sawant, "Life-cycle cost and financial analysis of energy components A case study in sub-urban India," International Journal of Sustainable Built Environment, vol. 4, pp. 202-221, July 2015.

[10] Johan Norden, Henrik Karlsson, Caroline Markusson, Svein Ruud, Mikael Lindgre and Patrik 011as, "Changing to energy efficient light sources - An analysis of the energy balance of buildings," Energy Procedia, vol. 78, pp. 2657-2662, 2015.

[11] Awanish Kumar, Shashi Ranjan, M. Bharath Kumar Singh, Priyanka Kumari, and L. Ramesh, "Electrical energy audit in residential house," Procedia Technology, vol. 21, pp. $625-$ 630,2015

[12] Umberto Berardi, "Building energy consumption in US, EU, and BRIC countries," Procedia Engineering, vol. 118, pp. 128-136, 2015

[13] J. P. Holman, Heat Transfer, 10th ed. New York: McGrawHill, pp. 350-357,2010, ISBN 978-0-07-352936-3.

[14] Promparn Sae Jung, Tanaporn Krittayanawach, Phichamon Deedom, and Bundit Limmeechokchai, "An experimental study of Thermo-Syphon solar water heater in Thailand," Energy Procedia, vol. 79, pp. 442 447, 2015. 